\title{
Tuberous sclerosis in pregnancy: a rare genetic disease requiring multidisciplinary approach in pregnancy
}

\author{
Shikha Madan ${ }^{1}$, Pardeep Kumar ${ }^{2 *}$, Smriti Anand ${ }^{1}$, Savita Singhal', \\ Neetu Sangwan ${ }^{1}$, Monika Dalal ${ }^{1}$
}

\begin{abstract}
${ }^{1}$ Department of Obstetrics and Gynecology, PGIMS, Rohtak, Haryana, India
${ }^{2}$ Department of Anaesthesia, PGIMS, Rohtak, Haryana, India
\end{abstract}

Received: 28 April 2020

Accepted: 30 May 2020

*Correspondence:

Dr. Pardeep Kumar,

E-mail: pardeepjakhar28@gmail.com

Copyright: ( ) the author(s), publisher and licensee Medip Academy. This is an open-access article distributed under the terms of the Creative Commons Attribution Non-Commercial License, which permits unrestricted non-commercial use, distribution, and reproduction in any medium, provided the original work is properly cited.

\begin{abstract}
Tuberous sclerosis complex (TSC) is a multisystemic, autosomal dominant genetic disorder with complete penetrance, that can evolve with hamartomas in multiple organs, such as skin, central nervous system, kidney and lung. Penetrance in genetics is the proportion of individuals carrying a particular variant (or allele) of a gene (the genotype) that also express an associated trait (the phenotype). Due to the wide phenotypic variability in TSC, the disease is often not recognized. The diagnostic criteria for tuberous sclerosis were reviewed in 2012, at the second International tuberous sclerosis complex consensus conference. The diagnosis is based on genetic criteria, by the identification of inactivating pathogenic mutation of tumour suppressor genes TSC1 and TSC2, and clinical criteria, including cutaneous, renal, pulmonary, cardiac and neurological manifestations. Authors present with a rare case report of a patient with TSC presenting at term.
\end{abstract}

Keywords: Angiofibrom, Tuberous sclerosis complex

\section{INTRODUCTION}

Tuberous sclerosis complex (TSC) is a multisystemic autosomal dominant disease that manifests with the growth of benign hamartomas in various organ systems, including the central nervous system, kidneys, and skin. TSC has an incidence rate of one in 6000 to one in 10,000 new-borns. ${ }^{1-3}$ It is also known as epiloia or Pringle-Bourneville phacomatosis, and was initially described in the $19^{\text {th }}$ century by Virchow and Von Recklinghausen, who identified hamartomas in the brain and heart during the necropsy of patients with seizures and mental retardation. However, the correlation between the cutaneous manifestations with other clinical symptoms and the description of the syndrome were made by Bourneville in the beginning of the $20^{\text {th }}$ century. Years after, Campbell in 1905 and Vogt three years later established the triad that characterizes TSC, which is mental retardation, epilepsy and Pringle type of sebaceous adenoma (angiofibroma).,

Diagnostic criteria for tuberous sclerosis were firstly established in $1998 .^{6}$ In 2012, in the second International tuberous sclerosis complex consensus conference held in Washington, these criteria were reviewed with the aim of presenting recommendations for the diagnosis, surveillance and management of TSC patients. ${ }^{6}$ Clinical criteria are divided into major: hypopigmented macules ( $\geq 3$, with at least $5 \mathrm{~mm}$ diameter), angiofibromas $(\geq 3)$ or fibrous cephalic plaque, ungual fibromas $(\geq 2)$, shagreen patch, multiple retinal hamartomas, cortical dysplasia, subependymal nodules, subependymal giant cell astrocytoma, cardiac rhabdomyoma, lymphangioleiomyomatosis, angiomyolipomas $(\geq 2)$; and minor: "confetti" lesion, enamel pits $(>3)$, intraoral fibroma ( $\geq 2)$, retinal hypopigmented macule, multiple renal cysts and nonrenal hamartomas (Table 1). The 
definitive diagnosis is defined by the presence of two major criteria or one major and two minor criteria. Probable diagnosis is made with one major criteria or two or more minor. ${ }^{6}$

\section{CASE REPORT}

Authors report a case report of an unbooked patient, 32 years old, diagnosed with Tuberous Sclerosis after having adverse event in first pregnancy (Figure 1).

Table 1: Clinical criteria for the diagnosis of tuberous sclerosis complex. ${ }^{12}$

\begin{tabular}{|ll|}
\hline $\begin{array}{l}\text { Major criteria } \\
\text { Hypomelanotic macules } \\
(\geq 3, \geq 5 \text { mm in diameter) }\end{array}$ & "Confetti" skin lesions \\
\hline $\begin{array}{l}\text { Angiofibromas }(\geq 3) \text { or } \\
\text { fibrous cephalic plaque }\end{array}$ & $\begin{array}{l}\text { Dental enamel pits } \\
(>3)\end{array}$ \\
\hline Ungual fibromas $(\geq 2)$ & Intraoral fibroma $(\geq 2)$ \\
\hline Shagreen patch & Retinal achromic patch \\
\hline Multiple retinal hamartomas & Multiple renal cysts \\
\hline Cortical dysplasia & Nonrenal hamartomas \\
\hline Subependymal nodules & \\
\hline $\begin{array}{l}\text { Subependymal giant cell } \\
\text { astrocytoma }\end{array}$ & \\
\hline Cardiac rhabdomyoma & \\
\hline Lymphangioleiomyomatosis & \\
\hline Angiomyolipomas $(\geq 2)$ & \\
\hline
\end{tabular}

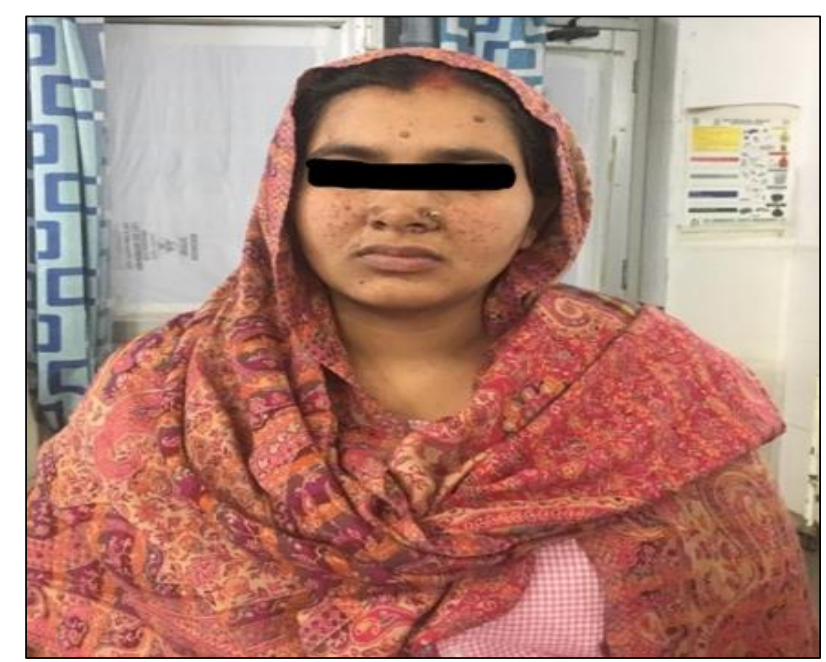

Figure 1: A patient with Tuberous Sclerosis with term pregnancy.

Patient was second gravida with previous caesarean section, 37 weeks, with no live issue. On history, it was found that she presented with adolescent onset epilepsy. She was on antiepileptic drugs since then. In her first pregnancy, she underwent caesarean section at 34 weeks in view of fetal distress. She had early neonatal death. She later got investigated, and was diagnosed as having Tuberous sclerosis on genetic criteria and clinical criteria. On examination, she had angiofibroma (adenoma sebaceous) with cephalic plaque (Figure 1). On ultrasound examination, no anomaly was found in abdomen, kidneys, adrenals. CT head was previously done, which showed sub ependymal calcified tubers for which she was already on antiepileptics. Fetal sonography was done which ruled out any congenital malformation. Patient underwent caesarean section at 37 weeks in view of fetal distress. Both patient and baby were discharged from hospital on $7^{\text {th }}$ day and kept on follow-up.

\section{DISCUSSION}

TSC occurs due to the deletion, rearrangement and inactivating mutation of tumour suppressor genes TSC1 or $\mathrm{TSC} 2$, that lead to abnormal proteins hamartin and tuberin, codified in the loci 9p34 and 16p13, respectively. 7,8 The role of these genes consists in the regulation of cellular growth through the phosphatidylinositol 3-kinase signaling pathway, inhibiting the mammalian target of rapamycin (mTOR). ${ }^{9}$ The complex hamartin/tuberin is an important inhibitor of tumour growth. These proteins suppress the activity of the mTOR pathway, responsible for cellular proliferation and inhibition of cellular apoptosis. In TSC patients, changes in these proteins lead to a permanent activation of the mTOR pathway, and therefore to the formation of hamartomas in multiple organs. Familial cases of the condition are due to germline mutations and, despite being able to be transmitted hereditarily, $70 \%$ of TSC patients are the result of somatic mutations, configuring sporadic cases. ${ }^{4}$ Studies demonstrate that changes in the TSC2 gene are more common and lead to a more severe neurological impairment when compared to TSC due to mutations in TSC1. ${ }^{2,10,11}$ Cases of familial transmission result in mild to moderate disease, sometimes not fulfilling all diagnostic criteria and have a higher frequency of changes in the TSC1 gene.

\section{CONCLUSION}

TSC treatment consists, above all, of the management of the symptoms caused by hamartomas in early life. Because it is a systemic disease, a multidisciplinary follow-up is mandatory involving obstetrician, neurologist, nephrologist, paediatrician. The treatment of obstetric patients with tuberous sclerosis complex is variable, due the variable phenotypes. Also, the cases reported in literature are very few. Thus, authors present such a rare case with a successful feto-maternal outcome.

Funding: No funding sources

Conflict of interest: None declared

Ethical approval: Not required

\section{REFERENCES}

1. Curatolo P, Moavero R, de Vries PJ. Neurological and neuropsychiatric aspects of tuberous sclerosis complex. Lancet Neurol. 2015;14:733-45. 
2. DiMario FJ, Sahin M, Ebrahimi-Fakhari D. Tuberous sclerosis complex. Pediatr Clin North Am. 2015;62:633-48.

3. Baron Y, Barkovich AJ. MR imaging of tuberous sclerosis in neonates and young infants. AJNR Am J Neuroradiol. 1999;20:907-16.

4. Rodrigues DA, Gomes CM, Costa IMC. Tuberous sclerosis complex. An Bras Dermatol. 2012;87:18496.

5. Hinton RB, Prakash A, Romp RL, Krueger DA, Knilans TK. International tuberous sclerosis consensus group. Cardiovascular manifestations of tuberous sclerosis complex and summary of the revised diagnostic criteria and surveillance and management recommendations from the International tuberous sclerosis consensus group. J Am Heart Assoc. 2014;3:e01493.

6. Northrup H, Krueger DA. International tuberous sclerosis complex consensus group. Tuberous sclerosis complex diagnostic criteria update: recommendations of the 2012 International tuberous sclerosis complex consensus conference. Pediatr Neurol. 2013;49(4):243-54.

7. Sadowski K, Kotulska K, Schwartz RA, Józwiak S. Systemic effects of treatment with mTOR inhibitors in tuberous sclerosis complex: a comprehensive review. J Eur Acad Dermatol Venereol. 2016;30:586-94.
8. Jacks SK, Witman PM. Tuberous sclerosis complex: an update for dermatologists. Pediatr Dermatol. 2015;32:563-70.

9. MacKeigan JP, Krueger DA. Differentiating the mTOR inhibitors everolimus and sirolimus in the treatment of tuberous sclerosis complex. Neuro Oncol. 2015;17:1550-9.

10. $\mathrm{Ng} \mathrm{KH}, \mathrm{Ng} \mathrm{SM}$, Parker A. Annual review of children with tuberous sclerosis. Arch Dis Child Educ Pract Ed. 2015;100:114-21.

11. Au KS, Williams AT, Roach ES, Batchelor L, Sparagana SP, Delgado MR, et al. Genotype/phenotype correlation in 325 individuals referred for a diagnosis of tuberous sclerosis complex in the United States. Genet Med. 2007;9:88100.

12. Portocarrero LKL, Quental KN, Samorano LP, Oliveira ZNP, Rivitti-Machado MCM. Tuberous sclerosis complex: review based on new diagnostic criteria. An Bras Dermatol. 2018;93(3):323-31.

Cite this article as: Madan S, Kumar P, Anand S, Singhal S, Sangwan N, Dalal M. Tuberous sclerosis in pregnancy: a rare genetic disease requiring multidisciplinary approach in pregnancy. Int J Reprod Contracept Obstet Gynecol 2020;9:3075-7. 